\title{
Kırıkkale Üniversitesinde Çalışan Öğretim Elemanlarının Sporla İlgili Alışkanlıkları
}

\author{
Sporting Habits of the Academic Staff Working for Kırıkkale University
}

\author{
Rüstem ORHAN ${ }^{1}$, Mehmet ÖÇALAN ${ }^{2}$, Nuray BAYAR MULUK ${ }^{3}$, \\ Osman Kürşat ARIKAN ${ }^{4}$
}

${ }^{1}$ Kırıkkale Üniversitesi, Dış İlişkiler ve AB Koordinasyon Birimi, KIRIKKALE

${ }^{2}$ Kırıkkale Üniversitesi, Beden Ĕgitimi ve Spor Bilimleri Fakültesi, KIRIKKALE

${ }^{3}$ Kırıkkale Üniversitesi, Tıp Fakültesi, KBB Anabilim Dalı, KIRIKKALE

${ }^{4}$ Adana Numune Ĕgitim ve Araştırma Hastanesi, KBB Kliniği, ADANA

\begin{abstract}
ÖZET
Bu çalışmanın amacı; Kırıkkale Üniversitesinde görev yapan öğretim elemanlarının sporla ilgili alışkanlıkların belirlemektir. Araştırmanın evrenini Kırıkkale Üniversitesi öğretim elemanları, örneklemini ise bazı akademik birimlerde görev yapan ve rastgele örnekleme yöntemiyle belirlenen 68 öğretim elemanı oluşturmaktadır. Araştırmanın problemine ilişkin olarak, öğretim elemanlarının kişisel bilgileri ile sporla ilgili alışkanlıklarını tespit etmek amacıyla 21 sorudan oluşan bir anket uygulanmıştır. Araştırmaya katılan öğretim elemanlarının \%69,1'i erkektir. Öğretim elemanlarının \% 64,7'si spor yaptıklarını, \%43,2'si spor yapma nedeni olarak sağlığını korumak olarak belirtirken \%37,5'i ise zaman yetersizliğinden dolayı spor yapamadıklarını belirtmişleridir.

Sonuç olarak Kırıkkale Üniversitesindeki öğretim elemanlarının yaklaşık yarısı spor yapmaktadır. Bununla birlikte spor yapan öğretim elemanı sayısının orta düzeyde olduğu, üniversitemizde rekreatif alanların düzenlenmesi, sportif faaliyetlerin daha iyi duyurulması ve yüzme havuzunun yapılması ile spor yapan öğretim elemanı sayının artacağı düşünülmektedir.
\end{abstract}

Anahtar Kelimeler: Kırıkkale Üniversitesi, ögretim elemanı, spor, boş zaman
ABSTRACT

The aim of this study is to find out sporting habits of the academic staff working for Kırıkkale University. The sample group consists of 68 people who have been selected randomly among the members of the academic staff of Kırıkkale University. In order to determine the sporting habits along with personal information, a survey consisiting of 21 questions has been conducted.

The people who took part in the survey, $69,1 \%$ were men. $64.7 \%$ of the teaching staff stated have done sports, $43.2 \%$ them stated to protect the health for the reason of making sports; and $37.5 \%$ of them stated that they could not make sports due to lack of time.

As a result, about half of the academic staff of Kırıkkale University are involved in sports; therefore more recreative facilites should be provided in the campus area and sport events should be publicized better. It is clear from the survey that a swimming pool in the campus area will help increase the number of the people involved in sports.

Keywords: Kirlkkale University, academic staff, sport, leisure 


\section{GíRiş}

Yirmibirinci yüzyılın başarılı insan modeli artık tek bir konuda değil birçok alanda kendini yetiştiren ve uzmanlaşan insan olarak tanımlanmaktadır. $\mathrm{Bu}$ insan modeli Avrupa Birliğinin 2007-2013 yılları arasında sürdürdüğü "Hayat Boyu Öğrenme Programı" felsefesine de uygundur. Birçok alanda kendini yetiştiren, uzmanlaşan, iş ve sosyal hayatta başarılı olan insanların da zamanı etkin olarak kullandıkları bilinmektedir. Etkin zaman kullanımı içerisinde öğrenmeye, çalışmaya, araştırmaya yer olduğu gibi boş zamanı değerlendirmeye, eğlenmeye, hobi ve spor yapmaya da yer vardır. Boş zamanını rekreatif ve sportif faaliyetlere ayıran insanların çalışma ve sosyal hayatta daha başarılı oldukları bilinmektedir. Yukarıdaki tanımlamaya uygun insan modeli yetiştirmek için iş hayatının eskisi gibi ağır ve uzun olmadığı görülmektedir. Ondokuzuncu yüzyılın başlarında 14-15 saat olan çalışma süresi, 20. yüzyılın başında günlük 11-12 saate ve günümüzde de 8 saate kadar düşmüştür. Dünyadaki teknolojik gelişmelerin hızlanması insanların boş zamanlarını arttırmıştır; bu da boş zaman eğilimlerini gerekli kılmıştır (1).

Boş zamanların değerlendirme faaliyetleri içinde spor, önemli bir yer tutmaktadır. Spor, nitelikleri itibariyle yalnızca bir boş zaman faaliyeti olarak da düşünülmemelidir. Sporun nitelik ve öneminin günümüzde anlaşılması ve yaygınlaşmasında, boş zamanın sportif faaliyetlerle doldurulmasının yeri küçümsenemez. "Kitle sporu”, "Yaşam boyu spor", "Herkes için spor" ve "Sağlıklı yasam için spor", gibi sloganlarla, farklı cins, meslek ve statüdeki bireyler aktif olarak spora çekilmeye çalışılmış; ayrıca boş zaman faaliyetlerinde spor yapma eğilimlerini teşvik edilmiştir (2).

Günümüzde, spordan beklenen hem sosyalleşme ve sosyal dayanışma süreçlerini oluşturmak, hem de bu süreçlerde erişilen kazanımları korumak; yani, sosyal entegrasyonun birleştirici öğesi olarak kullanmaktır.
Sivil toplum örgütlerinin etkin bir biçimde fonksiyonel kulübünün aktif üyesidir. Bu ülkede engelliler ve hatta çocuklu annelere yönelik spor programlarının varlığı, çağdaş endüstriyel bir toplumda sporun yerini göstermektedir (3). Tüm dünya ülkelerinde sporun insanların yaşam kalitesinin arttırılmasında, sağlığın korunmasında ve geliştirilmesindeki etkinliği kabul edilen bir gerçektir. Düzenli spor yapmanın ruh ve beden sağlığı üzerine olumlu etkilerinin araştırmalarla belgelenmesinden sonra; spor her yaştaki insanlar için önerilmeye başlanmıştır. ABD'de ve Kanada'da "Physical fitness", Almanya'da "Trim Dich" ve diğer ülkelerde "Sport For All" ya da "Sport Pour Out" gibi tanıtılan isimlerle spor uygulamaları geniş halk kitlelerine hızla yayılmaktadır. Böylece birçok gelişmiş ülkenin herkes için spor anlayışını hayata geçiren uygulamalarını görmek mümkün olmaya başlamıştır. $\mathrm{Bu}$ ülkelerde, insanlarının boş zamanlarını aktif spor yaparak değerlendirebilecekleri pek çok kampanya çalışması yapılmaktadır. $\mathrm{Bu}$ kampanyaların hareket noktasını öncelikli olarak spor faaliyetlerinin günlük hayatın bir parçası haline getirme alışkanlığının kazandırılması, daha sonra da bu faaliyetleri olumlu bir şekilde değerlendirmek yatmaktadır (4).

Boş zamanları değerlendirme aktiviteleri üzerine yapılan bir araştırmada, akademisyenlerin bir haftalık çalışma programları boyunca, az bir zaman dilimini boş zamanın oluşturduğu görülmüş̧ür. Akademisyenler boş zamanlarında televizyon izleme, çocuklarıyla bilgisayar oyunu veya geleneksel oyun oynama ve spor salonlarına gitme şeklinde değerlendirmektedirler. Akademisyenler boş zaman aktivitelerine daha fazla katılmak istedikleri halde bunu yapamamaktadırlar. Akademisyenlerin hafta içi boş zamanlarının az olduğunu ve bu yüzden kişisel ve aile ile ilgili aktivitelere fazla zaman ayıramadiklarını belirtmişlerdir (5).

$\mathrm{Bu}$ çalışma Kırıkkale Üniversitesi'nde görev yapan öğretim elemanlarının sporla ilgili alışkanlıklarını belirlemek amacı ile yapılmıştır. 


\section{GEREÇ VE YÖNTEMLER}

$\mathrm{Bu}$ çalışma, 14-25 Şubat 2011 tarihleri arasında, Kırıkkale Üniversitesinin farklı akademik birimlerinde görev yapan akademik personele yürütülmüştür. Araştırmaya ilişkin olarak ilgili literatür taranarak araştırma problemi hakkında gerekli bilgilere yer verilmiştir. Ayrıca araştırmada veri toplama aracı olarak bir anket geliştirilmiş (Ek 1) ve bu anket yoluyla elde edilen verilerle araştırmanın problemine çözüm aranmıștır.

Araştırmanın evrenini, Kırıkkale Üniversitesi öğretim elemanları, örneklemini ise bazı akademik birimlerde görev yapan ve rastgele örnekleme yöntemiyle belirlenen 18'i kadın ve 47'si erkek olmak üzere cinsiyetini belirtmeyen 3 kişi ile toplam 68 öğretim elemanı oluşturmaktadır. Araştırmanın problemine ilişkin olarak, öğretim elemanlarının kişisel bilgileri ve spor alışkanlıklarını belirlemek ve hangi tür spor faaliyetlerine katıldıklarını tespit etmek amacı ile 21 sorudan oluşan bir anket uygulanmıştır. Anketten elde edilen verilerin yüzde ve frekans değerleri alınmış, bazı sorular için crosstab değerleri hesaplanarak tablolar haline dönüştürülmüştür. Öğretim elemanlarının ankete katılmaları hususunda sözlü onayları alındıktan sonra anket uygulanmıştır. Çalışma Helsinki Deklarasyonu'na uygun olarak yürütülmüştür (6).

\section{BULGULAR}

Öğretim Elemanlarının Kişisel Bilgileri Tablo 1'de gösterilmiştir. Araştırma kapsamına giren öğretim elemanlarının \%69,1'nin erkek, \% 39,7'sinin 41-50 yaş arasında, \%70,6'sının evli ve 61,7'sinin 3 çocuğu olduğu görülmektedir.

Tablo 1. Öğretim elemanlarının kişisel bilgileri

\begin{tabular}{|c|c|c|c|c|c|c|c|c|c|c|c|}
\hline & & $\mathrm{n}$ & $\%$ & & & $\mathrm{n}$ & $\%$ & & & $\mathrm{n}$ & $\%$ \\
\hline \multirow[b]{2}{*}{ 葛 } & Kadın & 18 & 26,5 & \multirow{6}{*}{ 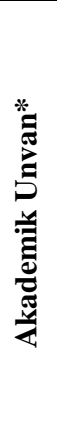 } & Prof. Dr. & 9 & 13,2 & \multirow[b]{2}{*}{ 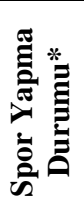 } & Evet & 44 & 64,7 \\
\hline & Erkek & 47 & 69,1 & & Doç. Dr. & 5 & 7,4 & & Hayır & 23 & 33,8 \\
\hline \multirow{4}{*}{$\stackrel{*}{*}$} & $20-30$ & 7 & 10,3 & & Yrd. Doç. Dr. & 11 & 16,2 & \multirow{5}{*}{ 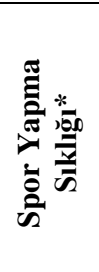 } & Haftada 1-2 gün & 14 & 20,6 \\
\hline & $31-40$ & 26 & 38,2 & & Öğr. Görevlisi & 15 & 22,1 & & Haftada $\geq 3$ gün & 8 & 11,8 \\
\hline & $41-50$ & 27 & 39,7 & & Okutman & 21 & 30,9 & & Ayda 1-2 gün & 12 & 17,6 \\
\hline & $\geq 51$ & 4 & 5,9 & & Araş. Görevlisi & 5 & 7,4 & & Tatillerde & 2 & 2,9 \\
\hline \multirow{2}{*}{ 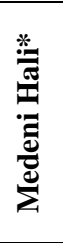 } & Evli & 48 & 70,6 & \multirow{4}{*}{ 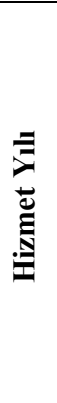 } & $1-10$ & 30 & 44,1 & & Firsat Buldukça & 14 & 20,6 \\
\hline & Bekar & 18 & 26,5 & & $11-20$ & 28 & 41,2 & 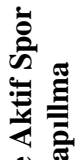 & Evet & 23 & 33,8 \\
\hline \multirow{3}{*}{ 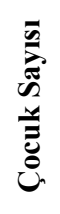 } & 1 & 9 & 26,5 & & $21-30$ & 4 & 5,9 & $\frac{e_{0}^{\circ}}{2}$ & Hayır & 30 & 44,1 \\
\hline & 2 & 24 & 61,7 & & $\geq 31$ & 1 & 1,5 & & & & \\
\hline & 3 & 4 & 11,8 & \multirow{2}{*}{ 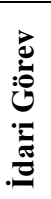 } & Evet & 31 & 45,6 & & & & \\
\hline & & & & & Hayır & 35 & 51,5 & & & & \\
\hline
\end{tabular}

*Spor yapma durumu bölümünde $1(\% 1,5)$, Cinsiyet bölümünde $3(\% 4,4$.$) , Yaş bölümünde 4(\% 5,9)$; Medeni Hal, Akademik Unvan ve İdari Görev bölümünde $2(\% 2,9)$, Hizmet Yılı bölümünde 5 (\%7,4); Ailede Aktif Spor Yapılması bölümünde 15 (\%22,1); Spor yapma sıklığı bölümünde $18(\% 26,5)$ kişi bu sorulara cevap vermemiştir. 
Ankete katılan öğretim elemanlarının \%30,9'nun okutman, \%44,1'inin hizmet yılının 1-10 yıl arasında ve \%45,6'sının idari görevi bulunduğu, \%64,7'sinin spor yaptığı ve \%33,8'inin ailesinde aktif spor yapan olduğu tespit edilmiştir.
Ankete katılan öğretim elemanlarının \%55,4’ü üniversitenin sportif etkinliklerini web sitesinden öğrendiği, \%60’ı BESYO (Beden Eğitimi ve Spor Yüksek Okulu) spor tesislerini kullandığ ${ }_{1}$ ve \%39,7’i spor için aylık herhangi bir harcamasının olmadığı görülmektedir (Tablo 2).

Tablo 2. Öğretim elemanlarının spor yapma durumlarını etkileyen faktörler ve spor yaptıkları yerler

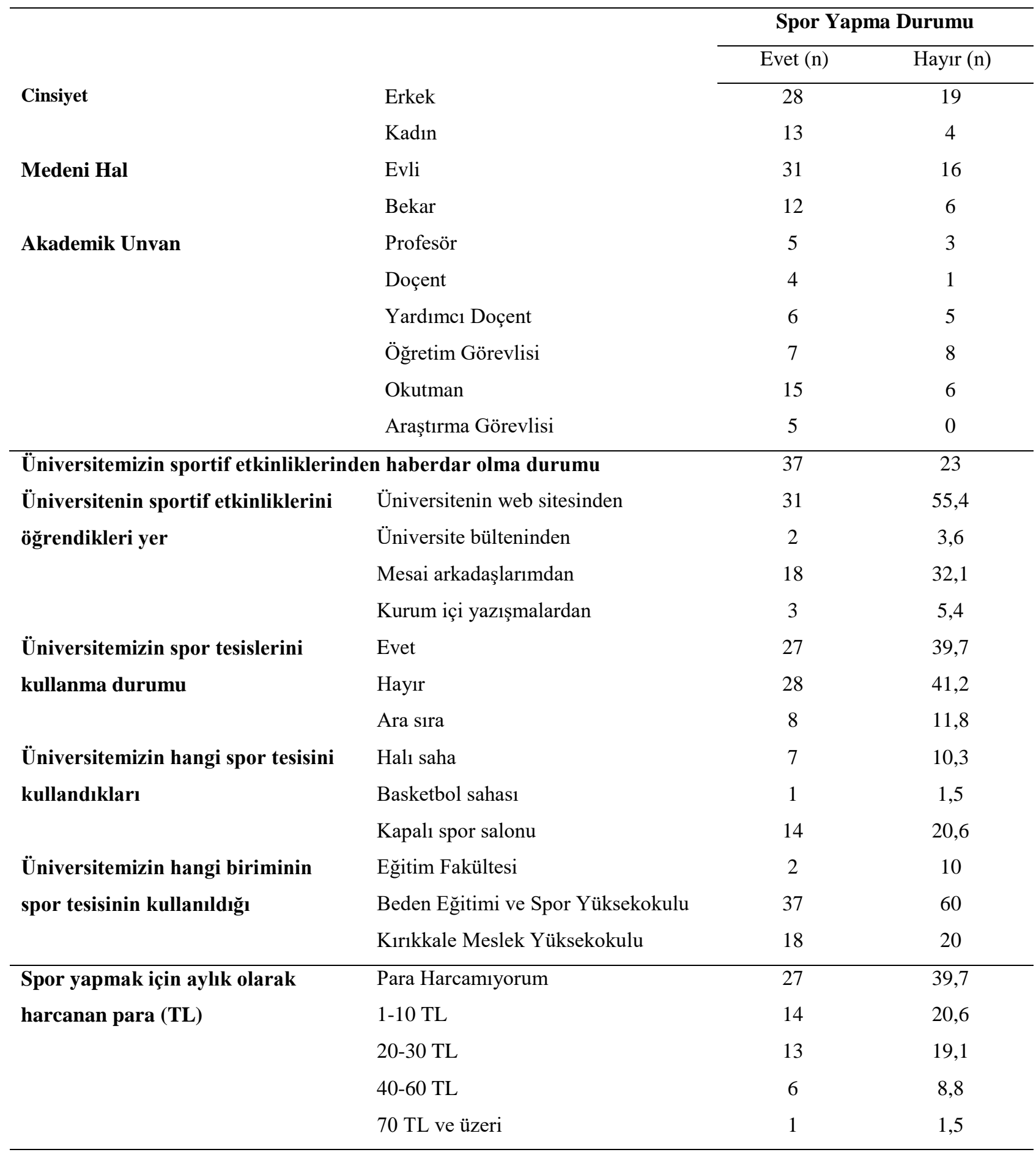




\section{KÜTFD}

Araştırmaya katılan öğretim elemanlarının "Hangi spor türünü yapıyorsunuz?" sorusuna verdikleri cevaplar arasında ilk üç sırayı Koşu $(\% 16,1)$, Futbol $(\% 12,1)$ ve Yüzme (\%11,3) sporu yer almaktadır (Şekil 1).

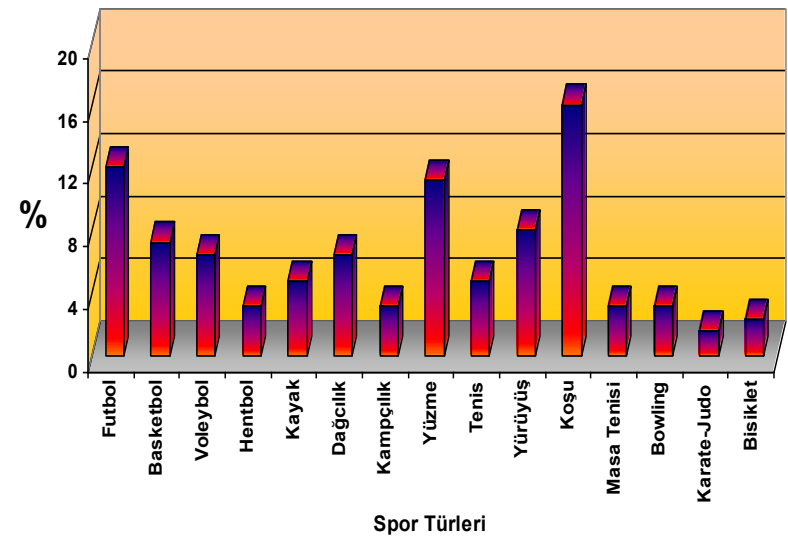

Şekil 1: Öğretim Elemanlarının Yaptıkları Spor Türleri

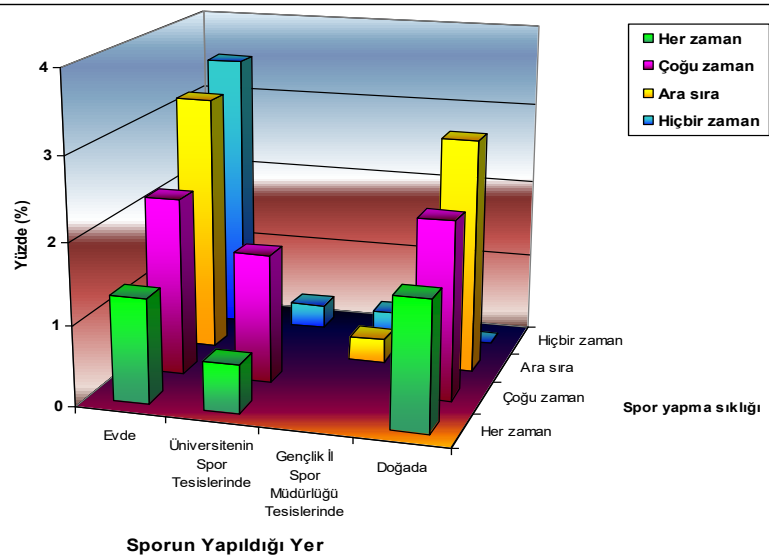

Şekil 2: Öğretim Elemanları Spor Faaliyetlerini Gerçekleştirdikleri Yerler

Öğretim elemanlarının spor faaliyetlerini nerede gerçekleştirdiklerine dair soruya verdikleri cevaplarda genellikle ev, doğa ve üniversitenin spor tesisleri olarak sıralanmaktadır. Gençlik İl Spor Müdürlüğünün tesislerinde, yüzme havuzunun kullanımı dışında spor yapma oranı ise çok düşüktür (Şekil 2). Öğretim elemanlarının \%43,2'si sağlığını koruma, \%13,7'si boş
Özgün Araştırma / Original Article

zamanlarını değerlendirme, \%10,5'i zayıflama ve \%21,1'i de spor yapmaktan zevk aldığı için spor yaptıklarını belirtmiş iken, \%35,5'i zaman yetersizliğinden, \%22,9'u spor tesislerinin yetersizliğinden, \%10,4’ü sağlı sorunu ve \%8,3’ü spor yapmaktan zevk almadığı için spor yapmadıklarını belirtmişlerdir (Şekil 3).

Çalışmamızda, öğretim elemanlarının \%32,5'i televizyondan, \%21'i gazeteden, \%26,8'i internetten ve \% 7,6's1 dergiden spor ile ilgili konuları takip ettiklerini belirtmişlerdir (Şekil 4).

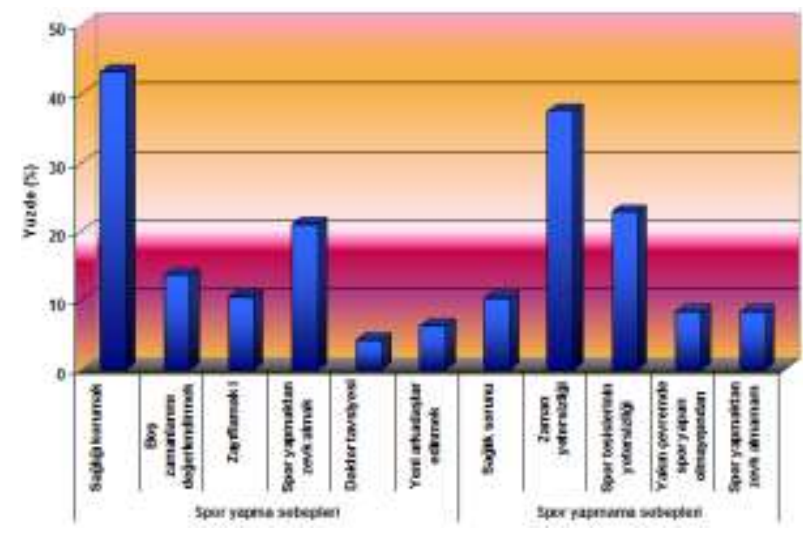

Şekil 3: Öğretim Elemanlarının Spor Yapma ve Yapmama Sebepleri

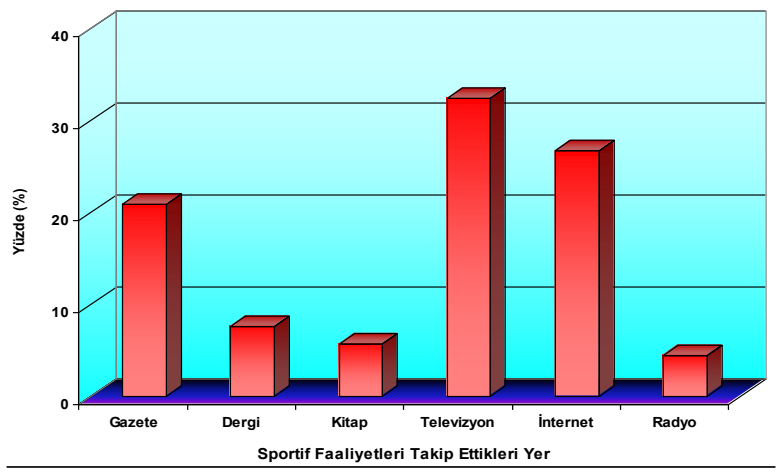

Şekil 4: Öğretim Elemanlarının Sportif Faaliyetleri Takip Ettikleri Yer 


\section{TARTIŞMA}

Kırıkkale Üniversitesinin akademik birimlerinde görev yapan öğretim elemanlarının spor ile ilgili alışkanlıkları üzerine yapılan bu araştırmada öğretim elemanlarının spor yapıp yapmadıkları, neden spor yaptıkları veya yapmadıkları, spor yapmak için ayırdıkları süre harcadıkları para miktarı üniversitemizin sportif faaliyetleri hakkında bilgi düzeyleri ve üniversitemizin spor tesislerini kullanma oranları araştırılmaya çalışılmıştır.

Çalışmamızda, araştırmaya katılan öğretim elemanlarının \%64,7'si spor yaptıklarını belirtirken, \% 20,6'sının da haftada 1-2 gün spor yaptıkları görülmüştür. Tel ve arkadaşlarının yaptıkları çalışmada öğretim üyelerinin \% 6's1 "hiçbir" şekilde spora zaman ayıramadığını belirtirken, diğer büyük çoğunluğun değişik sıklıklarda spor yaptıkları görülmüştür (2). Tel ve arkadaşlarının yapmış oldukları diğer çalışmada öğretim üyelerinin spor aktivitelerinden sıklıkla yaptıkları spor branşı ya da etkinliğinin, yürüyüş (\%37), futbol $(\% 11,3)$, raket sporları $(\% 8,1)$ ve yüzme $(\% 7,1)$ olduğunu bildirilmişlerdir (7). Arslan ve arkadaşlarının yaptığı diğer bir araştırmada ise öğretim üyelerinin sportif faaliyet yapma oranlarının düşük olduğu belirtmektedir. Öğretim üyelerinin haftalık fiziksel aktivite alışkanlıkları incelendiğinde 1. sırada \%48,3 ile yürüyüşün geldiği belirtilmektedir. Üniversite öğretim üyelerinin en fazla katıldıkları etkinlik yürüyüştür (8). Kadın öğretim elemanlarına yönelik yapılan bir araştırmada da en çok yüzmeyi daha sonrada yürüyüşü, tenis ve kayak sporunu tercih ettikleri görülmüştür (9). Öğretmenlerle yapılan bir araştırmada da öğretmenlerin \%64,8'inin boş zamanlarında spor yaptıkları tespit edilmiştir. Kadın öğretmenlerin \%52,2'sinin yürüyüş yaptı̆̆ı, erkeklerin \%46,2'sinin de futbol oynadığı görülmüştür. Kadın öğretmenlerin daha çok yürüyüş ve yüzme sporunu tercih ederken erkek öğretmenlerin ise futbol, yürüyüş ve masa tenisini tercih ettikleri belirtilmiştir (10).
Yapılan araştırmalar, rekreasyon amaçlı sportif faaliyetleri tercih eden insanların sayısının, diğer faaliyetlere katılanların sayılarından daha fazla olduğunu göstermektedir. Örneğin Almanya'da halkın \%61'i boş zaman etkinliklerinden sporu tercih etmektedirler. Ayrica 1987 yılında Almanya'da 6-16 yaş arasındaki 190.000 kişi üzerinde anket yoluyla yapılan bir araştırmada gençlerin \%60'ının boş zamanlarını spor yaparak geçirdikleri görülmüştür. Boş zamanlarda sportif faaliyetlere aktif katılmayı tercih etme oranının yüksek olmasındaki temel nedenler, sporun kişisel ve toplumsal özelliklerinden kaynaklanmaktadır (11). Bizim çalışmamızda, öğretim elemanlarının \%43,2'si spor yapma nedeni olarak sağlığını korumak olarak belirtmişken, \%37,5'i zaman yetersizliğinden dolayı spor yapamadıklarını belirtmişleridir. Çolakoğlu ve arkadaşlarının yaptığı araştırmaya göre, öğretim elemanlarının "Boş zaman etkinliklerine katılamama nedenlerine" bakıldığında \%47,1'i "Yeterli boş zaman olmayışı" şeklinde görüş bildirmişlerdir (12). Afyon ve arkadaşlarının yaptıkları araştırmada "Boş zaman etkinliklerine katılamama nedeni” olarak \%56'sı yeterli boş zamanının olmadığını belirmişlerdir (13). Öğretim elemanlarına "Boş zamanlarında en çok hangi alanlardaki etkinliklerle ilgilendikleri” sorusuna profesörlerin $\% 62$ 'si, doçentlerin \%57,1'i, yardımcı doçentlerin \%40'1, öğretim görevlilerin \%33'ü, okutmanların \%35'i "Boş zamanlarında en çok bilimsel uğraşlarla zaman geçirdiklerini” belirtmişlerdir. Zamanlarının geri kalanlarında ise edebiyat ve sanatla, çok azı da sporla uğraştıklarını belirtmişlerdir. Boş zaman tanımı, işin dışında kalan zaman olmasına rağmen, öğretim elemanlarının "İş dışında da iş" yaptıklarını belirtmeleri ilginç bir durum oluşturmaktadır (9). Yapılan diğer bir araştırmada öğretim elemanlarının \%95,1'inin sağlığını koruma isteğinden dolayı spor yaptığ1 görülmüştür (7). 
23 KÜTFD

Yapılan tüm bu çalışmalarda eğitim camiasının spor yapma oranının orta düzeyde olduğu tespit edilmiştir. Spor yapma nedeni olarak sağlığı koruma üst sıralarda yer alırken, spor yapamama nedeni olarak vakit yetersizliği ilk sırada yer almaktadır. Akademik çalışma, yoğun ders programı, konferans, toplantı, akademik-idari görevler ve danışmanlık gibi etmenler öğretim elemanlarının vakitlerini aldığı bir gerçek. Fakat tüm bu vakit alıcı unsurların yanında artık neredeyse tüm kampüslerde sportif faaliyetlerin gerçekleştirilebileceği modern spor tesislerinin olduğu, düzenli bir yaşam tarzında çalışmanın yanında spora da yer ayrılabileceği bir vakadır.

Sonuç olarak, Kırıkkale Üniversitesinde görev yapan öğretim elemanlarının spor ile ilgili alışkanlıkları incelenmiş ve çalışmaya katılan öğretim elemanlarından \%64,7'sinin spor yaptıklarını belirtmişlerdir. Öğretim elemanlarının üniversitemizin sportif faaliyetlerinden haberdar oldukları,
Özgün Araştırma / Original Article

üniversitemizin spor tesislerini kullandıkları ve imkânları olsa yüzmek istedikleri ortaya çıkmıştır. Öğretim elemanlarının çalışma saatlerinin fazla olduğu, sportif faaliyetlere fazla zaman ayıramadıkları, ortam ve şartların uygun olması durumunda çeşitli sportif etkinliklere katılabilecekleri tespit edilmiştir. $\mathrm{Bu}$ bulgulardan hareketle, insanların çalışma kadar dinlenmeye de ihtiyacı olduğu, çalışma saatlerinin daha makul ölçülere indirilebileceği, üniversitelerde öğretim elemanlarına yönelik yapılan sosyal-kültürel ve sportif faaliyetlerin artırılması ve çeşitlendirilmesi daha etkin bir şekilde duyurulması ve böylelikle öğretim elemanlarının çalışma veriminin artabileceği söylenebilir.

Daha sağlıklı ve verimli bir çalışma ortamının sağlanabilmesi için, kampüs alanında daha fazla spor yapma imkânı oluşturulmalı, rekreatif faaliyetlere yönelik çalışmalar artırılmalı ve yüzme havuzunun yapılması sağlanmalıdır. 


\section{Ek-1: Kırıkkale Üniversitesi’nde Çalışan Akademik Personelin Sporla İlgili Alışkanlıkları Anketi}

Bu anket, Kırıkkale Üniversitesi’nde çalışan akademik personelin spor yapma, sportif faaliyetleri izleme ve sporla ilgili konuları okuma alışkanlıklarını ortaya çıkarmak üzerine hazırlanmıştır. Katkınız için teşekkürler.

KİŞISEL BILGGILER

Cinsiyetiniz: $\mathrm{K} \square \quad \mathrm{E} \square \quad$ Yaşınız: ..........

Unvanınız: $\quad$ Prof. Dr. $\square \quad$ Doç. Dr. $\square \quad$ Yrd. Doç. Dr. $\square$ Öğrt. Gör. $\square \quad$ Okutman $\square \quad$ Arş. Gör. $\square \quad$ Uzman $\square$

Görevli bulunduğunuz akademik birim/bölüm:

Haftalık ders yükünüz (saat):

Üniversitedeki hizmet yılınız:

İdari göreviniz var mı? Evet

Hayır $\square$ Cevabınız evet ise idari görevinizi belirtiniz:

Medeni haliniz: Evli $\square$ Bekâr $\square$ Çocuk sayısı: ......

\section{SORULAR}

1. Spor yapıyor musunuz? a) Evet $\square \quad$ b) Hayır

2. Sporu hangi sıkılıkla yapıyorsunuz?
a) Haftada 1-2 gün
b) Haftada 3 ve daha fazla gün
c) Ayda 1-2 gün
d) Tatillerde
e) Firsat
Buldukça $\square$

3. Hangi spor türünü yapıyorsunuz? (Birden fazla seçenek işaretleyebilirsiniz)

$\begin{array}{llllllll}\text { Futbol } & \square & \text { Kayak } & \square & \text { Tenis } & \square & \text { Bowling } & \square \\ \text { Basketbol } & \square & \text { Dağcılı/Kampçılık } & \square & \text { Yürüyüş } & \square & \text { Karate,Judo vb. } \square \\ \text { Voleybol } & \square & \text { Kampçılık } & \square & \text { Koşu } & \square & \text { Kürek/Yelken } & \square \\ \text { Hentbol } & \square & \text { Yüzme } & \square & \text { Masa Tenisi } & \square & \text { Bisiklet } & \square\end{array}$

Diğeri (lütfen belirtiniz):

4. Ailenizde aktif spor yapan var mı? a) Evet $\square \quad$ b) Hayır

5. Spor faaliyetlerini nerede gerçekleştiriyorsunuz? İlgili sayının üzerine bir çarpı işareti koyunuz.

\begin{tabular}{|c|c|c|c|}
\hline Hiçbir zaman & Ara sira & Çoğu zaman & Her zaman \\
\hline Evde.. & $1 \square$ & $2 \square$ & $3 \square$ \\
\hline Doğada.............................. & $1 \square$ & $2 \square$ & $3 \square$ \\
\hline Üniversitenin Spor Tesislerinde.......... & $1 \square$ & $2 \square$ & $3 \square$ \\
\hline Özel Spor Tesislerinde... & $1 \square$ & $2 \square$ & $3 \square$ \\
\hline Gençlik İl Spor Müd.Tesislerinde............ & $1 \square$ & $2 \square$ & $3 \square$ \\
\hline Diğeri (lütfen belirtiniz): .................. & $1 \square$ & $2 \square$ & $3 \square$ \\
\hline
\end{tabular}

6. Niçin spor yapıyorsunuz? (Birden fazla seçenek işaretleyebilirsiniz)
$\square$ Sağlığımı korumak için
$\square$ Boş zamanımı değerlendirmek için
$\square$ Zayıflamak için
$\square$ Yeni arkadaşlıklar edinmek için
$\square$ Spor yapmaktan zevk aldığım için
$\square$ Doktor tavsiyesi nedeniyle
$\square$ Diğer (lütfen belirtiniz):

7. Spor yapmıyorsanız nedenini belirtiniz? (Birden fazla seçenek işaretleyebilirsiniz)
$\square$ Sağlik sorunu
$\square$ Zaman yetersizliğinden
$\square$ Spor tesislerinin yetersizliği
$\square$ Yakın çevremde spor yapan olmayışından
$\square$ Spor yapmaktan zevk almamam
$\square$ Çevremden çekinmem
$\square$ Diğer (lütfen belirtiniz) 
8. Spor programlarını/müsabakalarını izliyor musunuz?
a) Evet
b) Hayır
c) Kismen
8. soru için cevabınız "Evet" ise lütfen 9. - 10. sorularını cevaplayınız.

9. Haftada ortalama olarak kaç saat spor programlarını/müsabakalarını izliyorsunuz?
a) En fazla 1 saat
b) 1-2 saat
c) 3-4 saat $\square$
d) 5-6 saat
e) 7 saat ve üzeri

10. En çok hangi spor programlarını/müsabakalarını izliyorsunuz? İzleme açısından 1'den 3'e kadar sıraya koyunuz.
a) Futbol
b) Basketbol
c) Diğeri $\square$ lütfen belirtiniz:

11. Spor müsabakalarını izlemek için ikamet ettiğiniz şehrin dışına çıkar mısınız?
a) Evet
b) Hayır
c) Ara sira

12. Sporla ilgili konuları nereden takip edersiniz? (Birden fazla seçenek işaretleyebilirsiniz)
$\square$ Gazete
$\square$ Dergi
$\square$ Kitap
$\square$ Televizyon
$\square$ Internet
$\square$ Radyo
$\square$ Diğer (lütfen belirtiniz):

13. Spor yapmak ve sporla ilgili konuları takip etmek için (spor malzemesi, gazete, dergi, paralı spor yayınları vb.) aylık ortalama kaç TL harciyorsunuz?
a) Para harcamiyorum
b) 1-10 TL
c) $20-30 \mathrm{TL}$
d) $40-60 \mathrm{TL}$
e) $70 \mathrm{TL}$ ve üzeri

14. Üniversitemizin sportif etkinliklerinden haberdar misinız?
a) Evet
b) Hayır
14. soru için cevabınız "Evet" ise lütfen 15. soruyu cevaplayınız.

15. Üniversitenin sportif etkinlikleri nereden öğreniyorsunuz? (Birden fazla seçenek işaretleyebilirsiniz)
a) Üniversitenin web sayfasından
d) Kurum içi yazışmalardan
b) Üniversite Bülteninden
e) Diğer (lütfen belirtiniz)
c) Mesai arkadaşlarımdan

16. Üniversitemizin spor tesislerini kullanıyor musunuz?
a) Evet
b) Hayır
c) Ara sira
16. soru için cevabınız "Evet" ise lütfen 17. ve 18. soruları cevaplayınız;

17. Üniversitemizin hangi spor tesisini kullanıyorsunuz? Kullanma sıklığına göre 1'den 4'e kadar siralayınız.
a) Halı saha
b) Basketbol sahas
c) Kapalı spor salonu
d) Diğer (lütfen belirtiniz):

18. Hangi birimin spor tesislerini kullanıyorsunuz? Kullanma sıklığına göre 1'den 4'e kadar sıralayınız.
a) Eğitim Fakültesi
b) Beden Eğitimi ve Spor Yüksekokulu
c) Kırıkkale Meslek Yüksekokulu
d) Diğer (lütfen belirtiniz)

19. Üniversitemizin spor tesislerini yeterli buluyor musunuz?
a) Evet
b) Hayır
c) Kismen

20. Hangi tür spor tesis(lerinin) yapılmasını istersiniz? Lütfen belirtiniz

21. İmkânınız olsa hangi spor türünü yapmak isterdiniz?

$\begin{array}{lllllll}\text { Futbol } & \square & \text { Kayak } & \square & \text { Tenis } & \square & \text { Bowling } \\ \text { Basketbol } & \square & \text { Dağcılık } & \square & \text { Yürüyüş } & \square & \text { Karate, Judo vb. } \\ \text { Voleybol } & \square & \text { Kampçılık } & \square & \text { Koşu } & \square & \text { Kürek/Yelken } \\ \text { Hentbol } & \square & \text { Yüzme } & \square & \text { Masa Tenisi } & \square & \text { Bisiklet }\end{array}$

Diğer (lütfen belirtiniz) $\square$ 


\section{KAYNAKLAR}

1. Güngörmüş HA, Yetim AA, Çalık C. Ankara'daki Beden Eğitimi ve Spor Yüksekokullarında Görev Yapan Öğretim Elemanlarının Boş Zamanlarını Değerlendirme Biçimlerinin Araştırılması. Kastamonu Eğitim Dergisi. 2006; 14 (1): 285-298.

2. Tel M, Köksalan B. Öğretim Üyelerinin Spor Etkinliklerinin Sosyolojik Olarak İncelenmesi (Doğu Anadolu Örneği). Frrat Üniversitesi Sosyal Bilimler Dergisi. 2008; 18 (1): 261-278.

3. Voigt D. Spor Sosyolojisi (Çeviri: Ayşe Atalay). İstanbul. Alkım Yayınları 1998; 95.

4. Koparan Ş, Öztürk F. Uludağ Üniversitesi Personelinin Üniversite Sportif Olanaklarından Yararlanma Düzeyleri. Eğitim Fakültesi Dergisi. 2002; 1: 239-65.

5. Forgasz H, Leder G. Academics: how do they spend their time? Educational Research, Risks, and Dilemmas, 29/11/2003 to 03/12/2003, Australian Association for Research in Education (AARE) 2003; 1-16. http://www.are2003.org.nz

6. 52 $2^{\text {nd }}$ WMA General Assembly. World Medical Association Declaration of Helsinki: ethical principles for medical research involving human subjects. JAMA. 2000; 284: 3043-49.

7. Tel M. Öğretim Üyelerinin Boş Zaman Etkinlikleri Üzerine Sosyolojik Bir Araştırma: Doğu Anadolu Örneği. Fırat Üniversitesi Sosyal Bilimler Enstitüsü Sosyoloji Anabilim Dalı. Doktora Tezi 2007; 157, 159.
8. Arslan C, Koz M, Gür E, Mendes B. Üniversite Öğretim Üyelerinin Fiziksel Aktivite Düzeyleri ve Sağlık Sorunları Arasındaki İlişkinin Araştırılması. Fırat Üniversitesi Sağlık Bilimleri Enstitüsü Dergisi. 2003; 17 (4): 251.

9. Aydoğan İ, Gündoğdu FB. Kadın Öğretim Elemanlarının Boş Zamanlarını Değerlendirme Etkinlikleri. Sosyal Bilimler Enstitüsü Dergisi. 2006; 21: 217-32.

10. Kaya K, Tutal Y. Öğretmenlerin Boş Zamanlarında Sosyal ve Kültürel Etkinliklere Katılmaları İle İlgili Tutumları (Isparta Örneği). Süleyman Demirel Üniversitesi İktisadi ve İdari Bilimler Fakültesi Dergisi. 2005; 10 (2): 271-89.

11. http://www.sporbilim.com/sayfa.asp?mdl=haber\&p aram=68 (Received online at January, 2, 2013).

12. Çolakoğlu, T. Üniversite Öğretim Elemanlarının Boş Zaman Alışkanlıklarını Değerlendirmeleri Üzerine Bir Araştırma. Gazi Eğitim Fakültesi Dergisi. 2005; 25: 247-258.

13. Afyon YA, Hazar CA, Saygın Ö. Öğretim Elemanları ve Öğretmenlerin Boş Zamanlarını Değerlendirme Biçimlerinin Araştırılması. 1. Gazi Beden Eğitimi ve Spor Bilimleri Kongresi Bildiriler Kitab1; 2000; 2. Cilt: Sporda Psiko-Sosyal Alanlar/Spor Yönetim Bilimleri: 161-168. 